\title{
HEGEMONI MEDIA MASSA DAN PENTINGNYA MEMBANGUN KOMPETENSI KHALAYAK
}

\author{
Samsuar \\ Dosen Fakultas Ushuluddin Adab dan Dakwah \\ Institut Agama Islam Negeri Langsa \\ Email : samlangsa@gmail.com
}

\begin{abstract}
Abstrak
Kepemilikan media massa menjadi alat yang paling efektif dalam mengejar globalisasi dan hegemoni penguasa elit Atas khayak. Akibatnya media massa tidak memberikan ruang bagi masyarakat untuk berpartisipasi dalam proses produksi, yang menyebabkan kesenjangan antara media massa dan khalayak. Kemampuan literasi media bagi masyarakat yang hidup ditengah-tengah dunia sesak media (media satuarated world) dan pengaruh Hegemoni dipandang sebagai kebutuhan yang sangat mendesak untuk membangun kompetensi khalayak dalam mengendalikan isi media untuk kehidupan yang lebih baik.
\end{abstract}

Kata Kunci : Media. Hegemon, Literasi, Komunikasi.

\section{A. Pendahuluan}

Era reformasi bukan hanya membawah perubahan pada tatanan politik di Indonesia namun juga telah merubah secara mendasar dunia media massa di tanah air ini, bentuk perubahan tersebut bukan hanya terlihat dari jumlah media massa baik cetak maupun elektronik yang naik secara signifikan, pada sisi keragaman isi media dan perubahan sifat juga mengalami pergeseran seiring dengan perubahan iklim kebebasan pers (Iriantara, TT :45).

Perkembangan media massa di Indonesia pada sisi jumlah bisa dilihat dari menjamurnya stasiun televisi yang mengudara secara nasional yang naik menjadi dua kali lipat dibanding sebelum reformasi dari 6 stasiun menjadi 11 stasiun ini belum termasuk stasiun televisi yang yang mengudara secara regional yang berjumlah 70 stasiun dengan rincian 22 stasiun milik TVRI dan 48 stasiun milik pemerintah daerah dan swasta. Jumlah stasiun radio lebih banyak lagi tercatat 803 stasiun radio milik pemerintah dan swasta yang 
telah mengudara, ini belum termasuk media online dan media cetak yang tumbuh bak cendawan di musim penghujan serta radio komunitas yang dikelola oleh masyarakat secara komunitas dan mandiri.

Ada tiga hal yang menandai kecenderungan perkembangan media massa di Indonesia saat ini :

1. Pengelolaan usaha di bidang media massa tidak lagi dilakukan dalam bentuk yayasan yang hanya mengutamakan aspek idealnya namun telah berubah bentuk menjadi PT( Perseroan Terbatas) yang didukung sistem manajemen profesional serta mengarah pada komersialisme.

2. Semakin banyaknya para pengusaha nasional/ konglomerat yang memasuki bisnis usaha media massa.

3. Media massa yang ada semakin beragam bentuknya dan mengarah pada spesialisasi.

(Surat Edaran Dewan Pers No. 01/SE-DP/I/2014 Tentang Pelaksanaan UU Pers dan Standar Perusahaan Pers Pada poin pertama disebutkan setiap perusahaan pers harus berbentuk badan hukum Indonesia" (Pasal 9 Ayat (2) UU No. 40/1999). Sesuai Standar Perusahaan Pers, badan hukum Indonesia yang dimaksud di atas berbentuk Perseroan Terbatas (PT) atau badan-badan hukum lainnya yang dibentuk berdasarkan ketentuan peraturan perundang-undangan. Badan hukum lainnya yaitu yayasan atau koperasi. Sesuai Pasal 1 angka 2 UU Pers, badan hukum untuk penyelenggaraan usaha pers adalah badan hukum yang "secara khusus menyelenggarakan, menyiarkan, atau menyalurkan informasi." Dengan demikian, bentuk badan hukum untuk usaha pers tidak dapat dicampur dengan usaha lain selain di bidang pers. Hasil penelitian yang di lakukan oleh Centre for Innovation Policy and Governance (CIPG) dan HIVOS pada tahun 2012 lalu mencatat 12 grup usaha milik konglomerat (Grup MNC, Kompas Gramedia, Jawa Pos, Mahaka Media, Elang Mahkota Teknologi, CT Corp, Visi Media Asia, MRA Media, Femina, Tempo Inti Media, dan Beritasatu Media Holding.) yang menguasai dan mengendalikan ribuan media dengan aneka format. Untuk seluruh televisi di negeri ini, baik dalam tingkatan nasional maupun lokal, sebagian besar sahamnya hanya dimiliki oleh 5 orang saja, Aburizal Bakrie memiliki TVOne dan ANTV. Surya Paloh, memiliki MetroTV. Politisi, Hary Tanoesodibjo, memiliki RCTI, GlobalTV dan MNCTV. Chairul Tanjung memiliki TransTV dan Trans7. Eddy Kurnadi Sariaatmadja memiliki SCTV dan Indosiar).

Perkembangan media komersial yang seperti ini sebagaimana disebutkan Subianto telah menempatkan khalayak menjadi consumer yang mesti dipenuhi segala selera dan keinginannya dan bukannya sebagai warga negara atau publik yang harus dicerdaskan. Dengan kondisi tersebut media komersial menyajikan apa yang popular di masyarakat tanpa memperdulikan apakah acara tersebut melecehkan logika, mengacak-acak budaya, menumpulkan hati nurani atau mengabaikan kepentingan publik (Subianto, 2005)

Memang benar pada tingkat tertentu privatisasi dan komersialisasi telah meransang kreativitas dan inovasi dalam karya cipta dan industri kreatif dalam media massa terutama televisi, namun karena desakkan kompetisi yang ketat dam tekanan dari kepentingan investor 
dan pengiklan menyebabkan standar kualitas isi media semakin merosot dengan lebih mengutamakan kemasan santai, singkat dan asal menghibur. Tekanan nilai-nilai komersial yang berjalan bergandengan dengan konsentrasi kepemilikan pada akhirnya akan melahirkan hiperkomersialieme media dan terbukti telah menyingkirkan budaya jurnalisme berkualitas dan jurnalisme investigative, sehingga komodifikasi media ternyata juga berpotensi mematikan bagi kreativitas artistik dan jurnalistik.

Para pengkaji media dan budaya kritis seperti yang disampaikan Idi Subandi telah menggunakan beberapa pendekatan khususnya pendekatan sosio-kultur media untuk memahami arti penting kehadiran media dalam kehidupan sehari-hari khalayak ( Subandi, $2014: 214)$ :

a. Media Sebagai Pembentuk.

Dalam pendekatan ini diyakini bahwa isi media memiliki kekuatan untuk mempengaruhi masyarakat, perpektif ini memfokuskan pada cara-cara media mempengaruhi masa depan khalayak, banyaknya tayangan seks dan kekerasan yang vulgar kemungkinan besar akan mempengaruhi khalayak sehingga dalam kehidupan nyata orang akan lebih dominan oleh kecabulan dan budaya perkosaan.

Pendekatan media sebagai pembentuk telah memicu kekhawatiran orang mengenai dampak kekuatan media terhadap segmen masyarakat, apalagi kalau digunakan untuk kepentingan ekonimo dan politik.

Pendekatan ini kemudia telah melahirkan berbagai penelitian yang berfokus pada efek media dan dampaknya pada berbagai kehidupan masyarakat dan organisasi social.

\section{b. Media Sebagai Cermin}

Pendekatan ini bukan hanya mengkaji bagaimana isi media membentuk khalayak namun bagaimana media merefleksikan atau mencerminkan masyarakat,peran utama media menurut pandangan ini adalah untuk mencerminkan kembali kepada khalayak perisrtiwaperistiwa,prilaku, identitas dan nilai-nilai yang penting. dalam pendekatan ini terasa penting karena melihat bagimana media mengikuti perubahan di masyarakat ketimbang melihat caracara media menyebabkan perubahan pada khalayaknya..

Dalam perspektif ini, jika media didominasi oleh tayangan seks dan kekerasan, hal ini biasanya disebabkan karena kita hidup ditengah-tengah masyarakat yang telah terbiasa dengan kekerasan dan kecabulan yang kerap terjadio dilingkungan mereka. Sepertih sebuah cermin media hanya memantulkan kekerasan yang telah ada di dunia nyata. Jika opini dan 
nilai-nilai tertentu sudah dianggap utama dalam isi media, ia sesungguhnya sekedar merefleksikan arus yang sedang berkembang di dalam masyarakat.

Menurut pendekatan ini berita merupakan sebuah produk yang netral yang hanya merefleksikandunia sekitarnya, Karena itu jika tidak menyukai sesuatu berita, maka jangan beritanya dikutuk namun kita harus sadar bahwa kita harus memperbaiki lingkungan kita, sehingga menjadi tempat yang nyaman untuk kita tempati.

Keyakinan bahwa media mencerminkan masyarakat telah mendorong beberapa penelitian komunikasi untuk mempelajari mengenai perubahan struktur, norma-norma budaya atau politik di dalam masyarakat yang sesungguhnya dengan mengkaji dari isi media.

\section{B. Media Sebagai Pengemas}

Dalam pandangan ini baik pendekatan yang menyatakan media sebagai pembentuk dan media sebagai cermin dianggap sangat simplistik, maka muncullah pandangan untuk memahami hubungan diantara keduanya sebagai hubungan sirkular, yang melibatkan unsurunsur kedua proses. Pendekatan media secagai cermin tetap berguna dalam mengigatkan khalayak bahwa isi media berhubungan erat dengan kejadian-kejadian nyata dan nilai-nilai budaya yang tengah berlakudi masyarakat.

Nnamun sesungguhnya isi media tidak mencerminkan peristiwa secara netral dan sempurna, Media terlebih dahulu akan menyeleksi apa yang akan dimasukkan dalam tayangan tersebut dan media menyajikan unsur-unsur yang mereka masukkan itu dengan cara-cara yang sangat khusus.

Sebenarnya media tidak menyajikan kepada khalayaknya sebuah cermin yang utuh melainkan suatu susunan representasi dunia yang sudah diseleksi dan dikemas sedemikian rupa, dengan demikian media bukanlah cermin yang netral namun sajian informasi yang diberikan merupakan tekanan yang selektif terhadap persperktif yang berorientasi tertentu karena representasi media merupakan hasil seleksi dan dikemas, dia berbeda dari dunia yang dicerminkan oleh media, pandangan inilah yang membawa pendapan bahwa media berpotensi mempengaruhi khalayaknya, tekanan atau informasi yang terus-menerus diberikan terhadap sebuah opini atau tema tertentu melalui media dan upaya menyingkirkan terus menerus atas informasi yang lain.

Model sirkular tentang representasi dan pengaruh media menjadi titik pijak untuk memahami proses terus menerus berlangsungnya reprentasi media secara selektif dan bagaimana hal tersebut dipengaruhi oleh kemasan dan karakter masyarakat. 


\section{Media Sebagai Guru}

Selain pendekatan media sebagai cermin, pembentuk dan pengemas, kita juga akan melihat posisi media yang telah menjadi guru atau pendidik yang mengajarkan pengetahuan dan nilai-nilai atau prilaku tertentu bagi segmen khalayak.

Kondisi dimungkinkan karena media saat ini telah menjadi rujukan utama khalayak untuk mengalami dan belajar tentang berbagai aspek dunia di sekitar khalayak termasuk belajar berprilaku konsumtif, sehingga muncul kecemasan dikalangan pendidik bagaimana anak-anak telah ditawarkan oleh media tentang pandangan hidup dan nilai-nilai yang berbeda dengan diajarkan oleh orang tua atau guru yang sesungguhnya di sekolah.

\section{Media Sebagai Ritual}

Media juga dipandang sebagai "agama sipil" dengan ritual-ritualnya yang menggantikan atau mengeser agama tradisional, selama 24 jam media massa terutama televisi merancang berbagai tayangan acara pada jam-jam tertentu secara sedemikian rupa sehingga menarik minat pemirsa agar selalu ditunggu-tunggu oleh khalayak. Pandangan ini melihat ritual khalayak yang menunggu-nunggu tayangan televisi seperti saat khalayak sedang menanti jadwal ritual keagamaan yang dijalani secara rutin pada waktu-waktu yang telah ditetapkan oleh ajaran agamanya dan dilakukan secara bersama-sama.

Acara-acara seperti sinetron atau pesta olahraga yang melibatkan banyak negara seperti piala dunia sepak bola telah menjadi peristiwa ritual di media dan dirayakan atau disembah oleh milyaran khalayak diseluruh pelosok dunia.

\section{E. Media Sebagai Tuhan}

Pandangan lebih ekstrem menyatakan bahwa media selain sebagai ritual saat ini media telah menjadi "tuhan" atau "agama baru" lebih dari sekedar menjadi guru atau media ritual bagai khalayak, saat ini media bahkan bagi sebagai pemirsa telah mengantikan peran "tuhan" dalam artian tradisional sebagaimana yang diyakini oleh penganutnya.

Media telah menjelma menjadi "tuhan Kedua" yang memerintahkan jalan kebaikan dan menawarkan jalan pemecahan untuk melawan keburukan berdasarkan versinya sendiri bagi khalayak.(Subandi, $2014: 8$ ).

"Tuhan-tuhan" media ini adalah bintang atau selebritas media, yakni figur-figur kemasan budaya popular yang mengkhotbahkan nilai dan gaya hidup tertentu yang harus diikuti oleh khalayak bila mereka ingin meraih harapan bahagia sebagaiman yang telah dijanjikan, mediaberubah menjadi penjual harapan dan impian.Televisi misalnya dengan 
sukses dan memikiat tanpa henti menawarkan budaya konsumtif dan iklan gaya hidup yang menganggap bahwa kebahagiaan bisa diraih dengan membeli suatu produk atau memiliki benda- benda material yang setiap hari ditawarkan oleh "tuhan-tuhan" media tadi.

Dengan mengingat media massa memiliki pengaruh terhadap kehidupan sosial khalayak, perubahan menjadi media yang berorientasi komersial berdampak pula terhadap pengaruh yang ditimbulkan media massa terhadap masyarakat. Salah satu dampak yang terlihat adalah kemunculan hegemoni gagasan dan agenda korporat terhadap publik. Akibatnya publik lebih mengikuti apa yang diinginkan perusahaan yang memamfaatkan media massa tersebut dan bukan mengikuti kebutuhan publik sendiri.

Dalam tradisi Cultural Studies yang dikembangkan oleh Stuart Hall, media merupakan instrument kekuasaan kelompok elit dan media berfungsi menyampaikan pemikiran kelompok yang mendominasi masyarakat terlepas apakah pemikiran itu berguna atau tidak.

Studi kultural menekankan pada gagasan bahwa media menjaga kelompok yang berkuasa untuk tetap memegang control atas masyarakat sementara masyarakat menerima apa saja yang disisakan kepada mereka oleh kelompok yang berkuasa pada sisi inilah bagaimana hegemoni media telah merubah tatanan budaya dalam masyarakat kita .

Istilah hegemoni sendiri berasal dari bahasa Yunani, egemonia, yang artinya penguasa atau pemimpin. Dalam pengertian yang ringkas, hegemoni dapat diartikan sebagai sistem kekuasaan atau politik kelas dominan untuk menguasai kelas di bawahnya dengan menggunakan kekuasaan itu.

Dalam pengertian Marxisme, hegemoni berarti terjadi dominasi kelas berkuasa terhadap kelas bawah. Mereka yang masuk ke dalam kelas berkuasa adalah mereka yang menguasai ekonomi. Kelas borjuis mengatasi kelas proletar . Dari pengertian ini, hegemoni dapat menjelaskan fenomena terjadinya upaya pelanggengan kekuasaan oleh kelompok penguasa dan kelompokkelompok lainnya juga. Tujuannya adalah menguasai wacana publik terhadap kelompok yang didominasi sehingga diterima sebagai sesuatu yang wajar.

Hegemoni penguasa terhadap kelompok yang didominasi bisa dilakukan dengan berbagai macam cara, di antaranya melalui saluran penyebaran informasi formal (media massa). Hegemoni atas tubuh media massa terjadi karena perkawinan antara dunia bisnis dengan politik. Melihat fenomena yang ada, media massa yang dimiliki oleh pebisnis ternyata juga digunakan sebagai upayanya untuk berkiprah di dunia politik.

Adalah Antonio Gramsci (1891-1937) yang menggagas teori hegemoni. Gramsci adalah seorang Marxian yang menjadi politikus Italia, yang sekaligus aktivis. Gramsci 
mendirikan Partai Komunis Italia, kemudian dipenjara ketika kaum Fasis menyerang tahun 1924, kemudian meninggal. Ketika dalam masa tahanan itulah ia menuliskan pemikirannya dalam bentuk catatan yang kemudian diterbitkan dalam bentuk buku dengan judul Selection FromPrison Notebooks ( Morissan, 2014 : 535). Tradisi marxisme, yang mempersoalkan hubungan borjuis-proletar, kemudian diturunkan oleh Gramsci ke berbagai persoalan sosial yang lain. Bukan hanya relasi politis antara majikan dan buruh, namun juga berbagai relasi sosial lain. Misalnya, gender, agama, ras, dan relasi antar kelompok sosial itu sendiri. Hegemoni bukan hanya beroperasinya dominasi lewat kekuatan politik, namun juga merupakan bentuk kepemimpinan intelektual dan moral. Apa yang menjadi wacana penguasa kemudian diikuti oleh masyarakat luas.

Lalu, bagaimana media massa melakukan "tugas"-nya? Dapat dijelaskan dengan singkat dan seperti ini. Kita mungkin pernah melihat spanduk di perempatan jalan yang berbunyi, "Awas bahaya laten komunisme!" Ini merupakan contoh kecil bagaimana penggunaan sebuah frasa atau (bahkan) kalimat digunakan untuk menggiring opini masyarakat. Penguasa menyampaikan pesan mereka melalui bahasa. Kemudian, (sengaja atau tidak) apa yang ditangkap oleh masyarakat tersebut menjadi wacana. Tentunya juga didukung dengan penggunaan media lain sebagai penyampai pesan.

Pembentukan opini masyarakat oleh media, menunjukkan bahwa wacana merupakan (alat) kekuasaan. Wacana mampu mengukuhkan kekuasaan elit tertentu. Meskipun dalam contoh ini tidak hanya dilakukan penguasa, dalam hal ini misalnya pemerintah, yang melakukan proses hegemoni. Namun setidaknya begitulah model pembentukan opini masyarakat. Penguasa melakukan penyebaran wacana melalui media massa, baik cetak maupun elektronik, bahkan hingga spanduk dengan opini penguasa. Tema tulisan atau gambar dalam media massa, menjadi hal yang mudah untuk kita indentifikasi ke arah mana opini masyarakat digiring.

Dalam ranah kekuasaan, dominasi penguasa dilakukan melalui dua cara, yakni penguasaan politis melalui militer dan berbagai kebijakan yang diterapkan, serta penguasaan wacana di media massa. Dominasi kekuasaan politik atau militer dikombinasikan dengan opini publik serta penerimaan publik terhadap kebijakan hegemonis tersebut. Sehingga, antara kekuatan dominasi dan penerimaan publik berjalan seimbang. Akibat dari hal ini, masyarakat menjadi "mayoritas yang diam" (silent majority). Masyarakat menjadi pasif dan menerima apa-apa yang dilakukan atau pun dikatakan oleh penguasa.

Untuk kasus di Indonesia, sepanjang sejarah Indoneia modern pemerintah selalu memandang pers sebagai bahaya pontensial yang menjadi saluran suara kaum oposisi, 
sehingga dengan ketakutan tersebut negara menjelma menjadi penguasa informasi dan menjadikan pers sebagai saluran propaganda untuk mengusung makna yang sudah mengalami hegemoni dan distorsi demi kepentingan status quo. Dengan berbagai cara pemerintah selalu berupaya mengontrol pers secara represif, dengan meneror kebebasan dengan memberangus penerbit dan menghilangkan nyawa wartawannya ( Ibrahim, 2011 : 72).

Pasca tumbangnya orde baru, prilaku pemilik media telah menjadi penguasa, mereka merumuskan percakapan ratusan juta warga Indonesia, media mengatur apa yang seharusnya dibicarakan dan apaya yang dihindari untuk dibicarakan, agenda publik menjadi pengejawatahan egenda pemilik media sekaligus pemiliki modal, akibatnya kerja media hanya memproduksi informasi berdasarkan apa yang diinginkan oleh pasar, bukan apa yang dibutuhkan oleh publik artinya selera konsumen yang telah diciptakan oleh media diposisikan seolah-olah merupakan selera publik.

Pada akhirnya publik kemudian oleh pemilik dan pengelola media sebagai konsumen sehingga pelayanan media kepada para pembaca, pendengar dan penonton berada dalam koridor transasi antara produsen dan konsumen,dengan mekanisme jual beli. Informasi yang diproduksi oleh media bukan untuk memberdayakan publik namun beralih memperdaya publik, Publik terpaku dengan isu-isu yang diagendakan oleh media yang sering sekali mengeser fokus substansi informasi yang diberikan informasi yang remeh-temeh.

Seperti pemberitaan yang ramai soal tato yang ada ditubuh Menteri Kelautan Susi Pudjiastuti yang baru dilantik Presiden Joko Widodo, media mengupas soal tato di kaki tersebut dan pendidikan susi, namun media tidak memberikan porsi yang sama besarnya untuk pemberitaan kebijakan yang akan dilakukan Susi selama menjadi menteri, ini merupakan sebuah bentuk dari pergeseran dari fokus pemberitaan yang sebenarnya harus dilakukan oleh media ( Thaniago, $2015: 7$ ). Khalayak diajak oleh media untuk menjauhi halhal yang substansial sebuah masalah dan di dekatkan ke hal-hal yang bombastis.

\section{F. Melek Media dan Prilaku Kehidupan}

Melihat fenomena di media massa saat ini kita sampai lupa bahwa media tersebut kehadirannya pada awalnya dimaksudkan untuk mendidik, menghibur, menginformasikan dan mempengaruhi, namun dalam praktiknya media massa ternyata mengajarkan kepada kita gaya hidup yang diyakini benar dan mengkhotbahkan nilai-nilai yang dipandang benar 
secara komersial, hal ini menjadi contoh bagaimana media massa telah menjungkirbalikkan nilai-nilai yang hidup dalam masyarakat kita.

Pada posisi inilah literasi media atau melek media harus kembali diteguhkan kehadirannya, pada dasarnya leterasi media merupakan pendidikan yang mengajari khalayak media agar memiliki kemampuan menganalisis pesan media, memahami bahwa media memiliki tujuan komersial/bisnis dan politik sehingga mereka mampu bertanggungjawab dan memberikan respon yang benar ketika berhadapan dengan media( Iriantara, $2019: 13$ ).

Pada tahap selanjunya literasi media memberikan pemahaman yang lebih mendalam kepada khalayak untuk dapat mengenali dan memahami informasi ke tahap yang lebih tinggi, selain kecakapan berpikir kritis seperti mempertanyakan, menganalisis dan mengevaluasi informasi media, juga kritis terhadap peran audiens (bahkan diri sendiri) dalam mengartikan atau menggunakan pesan media. Nantinya khalayak tidak hanya sebagai konsumen namun sekaligus produsen seiring perkembangan media saat ini yang memiliki karakter interaktivitas internet dalam telepon pintar yang tidak terhambat jarak dan waktu. Mongontrol diri tidak hanya dari pesan media yang menerpa, tetapi juga dari memaknai, memproduksi atau menggunakan pesan media secara etis.

Tidak melek terhadap informasi yang dibawa media menimbulkan berbagai permasalahan. Dari hasil penelitian yang dilakukan efek tidak melek media ini bagi anakanak, mulai dari kecanduan menonton tayangan televisi, bermain games online, chatting melalui social media, konten pornografi internet, infotainment, hingga berita kriminal.Anak-anak cenderung menginternalisasi pesan-pesan media dan mengintegrasikannya dalam pembentukan diri ( Herlina D, $2011: 24$ ).

Sementara efek tidak melek media ini bagi remaja, tidak melek media mengakibatkan perilaku konsumtif terutama terhadap pulsa internet, konten sinetron, musik, dan reality show. Remaja menganggap bahwa citra yang muncul di televisi adalah sesuatu hal yang nyata, sehingga mereka mencitrakan diri sebagai tokoh-tokoh sinetron dan penyanyi, mulai dari gaya berpakaian, potongan rambut, prilaku imitasi ini sampai terbawabawa dalam kehidupan sehari-hari ( Suprati , 2011 : 102).

Efek yang paling parah tentunya bagi ibu-ibu, terutama ibu-ibu rumah tangga yang banyak menghabiskan waktunya di rumah, selain menjadi konsumtif terutama terhadap barang-barang yang diiklankan di media, tidak melek media dapat mencontohkan perilaku kecanduan konten media pada anak, sampai dengan menyerahkan pengasuhan anaknya pada televisi Sukiratnasari, 2011 : 97) . 


\section{G. Gerakan Literasi Media}

Menurut Pasal 4 UU RI No.11 tahun 2008 mengenai Informasi dan Transaksi Elektronik (ITE), pemanfaatan teknologi informasi dan transaksi elektronik dilaksanakan dengan tujuan untuk: Mencerdaskan kehidupan bangsa sebagai bagian dari masyarakat informasi dunia; Mengembangkan perdagangan dan perekonomian nasional dalam rangka meningkatkan kesejahteraan masyarakat; Meningkatkan efektivitas dan efisiensi pelayanan publik; Membuka kesempatan seluas-luasnya kepada setiap orang untuk memajukan pemikiran dan kemampuan di bidang penggunaan dan pemanfaatan Teknologi Informasi seoptimal mungkin dan bertanggung jawab; Dan memberikan rasa aman,keadilan, dan kepastian hukum bagi pengguna dan penyelenggara Teknologi Informasi . Kelima tujuan mulia ini hanya bisa dicapai jika seseorang melek terhadap informasi sehingga cerdas dan mampu memilih informasi apa yang dibutuhkan.

Di beberapa negara seperti India, Jepan dan negara-negara di benua Eropa literasi media ini dilakukan dalam upaya "proteksi" atau perlindungan terhadap generasi muda dari kemungkinan pengaruh buruk dari media massa, mereka meneilai perlu diberikan keterampilan yang bisa melindungi generasi muda negaranya dari pengaruh buruk media massa.

Meski tingkat literasi biasanya berhubungan dengan tingkat pendidikan dan daya kritis masyarakat. Makin tinggi pendidikan dan daya kritis seseorang, makin tinggi tingkat literasinya. Namun dari beberapa penelitian tidak ada korelasi antara tingginya pendidikan dan melek media ( Novita A, 2015)

Sudah saatnya dilakukan gerakan sosial literasi media sebagai bentuk tekanan sosial terhadap media massa, kita tidak harus menunggu sampai sebuah tayangan media memakan korban terlebih dahulu seperti tayangan Smack Down, yang memakan korban anak tewas atau cedera karena meniru adegan tersebut untuk meminta media massa menghentikan tayangan tersebut.

Ada dua format gerakan sosial literasi media yang bisa dilakukan pertama gerakan boikot media dan boikot produk yang diiklankan oleh media, gerakan boikot media merupakan salah satu bentuk siklus aksi-refleksi atau siklus kesadaran-analisis-refleksi-aksi. Gerakan ini menyerukan kepada khalayak untuk tidak menonton, membeli atau mendegarkan media massa tertentu karena isinya tidak mengandung hal-hal yang dianggap baik secara sosial. Boikot tidak membeli majalah Playboy edisi Indonesia misalnya lebih baik dilakukan dari pada datang berdemotrasi ke kantor redaksi tersebut dan merusak isi kantor serta memukul awak redaksinya. 
Memboikot produk dimaksudkan adalah memboikot produk yang iklannya tampil dalam satu acara ditelevisi, radio, media online atau media cetak yang tidak sejalan dengan nilai-nilai yang berlaku dalam masyarakat. Iklan yang muncul pada acara gosip ( ghibah) misalnya sebuah acara yang dipandang lebih banyak membawa mudarat ketimbang mamfaat bagi khalayak, maka upaya yang dilakukan oleh khalayak adalah "memotong nyawa" acara tersebut yakni tidak membeli semua produk barang atau jasa yang iklannya ada diacara tersebut.

Upaya ini sangat jitu dilakukan karena media massa tidak bisa hidup tanpa mengandalkan pemasukan dana dari iklan, dengan pemboikotan pembelian produk yang iklannya tampil diacara tersebut dengan sendirinya produsen produk yang diiklankan akan berfikir dua kali untuk menampilkan iklan produk mereka diacara-acara "sampah" seperti itu, pemilik media masa juga akan berfikir ulang untuk memproduksi acara yang tidak bermutu.

Satu hal yang penting diingat gerakan sosial literasi media bukan merupakan gerakan yang anti media massa, gerakan ini hanya ingin mengembalikan media massa pada posisisnya sebagai media milik publik yang mengabdi pada kebaikan publik, media bukan semata sebagai mesin pencari uang bagi pemiliknya namun harus bisa memberikan apresiasi terhadap masyarakat luas dan tidak menghadirkan sesuatu yang bertentangan dengan rasa kesusilaan, rasa kedailan serta rasa kemanusiaan khalayaknya.

Akhirnya apa yang dilakukan oleh lembaga media watch seperti Remotivi yang setia memplototi semua tayangan televisi yang tidak mendidik dan berupaya mengkritisinya, serta beberapa lembaga pemantau media lain seperti KIPPAS di Sumatera Utara sepertinya tidak cukup, perlu kerja keras dan kesadaran kita bersama untuk menciptakan media sehat di sekitar kita gagasan pemboikotan media dan produk iklan hanya sebuah wacana yang kiranya layak untuk digagas ditengah-tengah khalayak, Untuk Aceh khusunya peran KPID dengan berbekal pasal 153 ayat 1 Undang-Undang Nomor 11 Tahun 2006 Tentang Pemerintahan Aceh, yang menyebutkan -Pemerintahan Aceh mempunyai kewenangan menetapkan ketentuan dibidang pers dan penyiaran berdasarkan nilai Islam perlu segera diwujudkan. 


\section{DAFTAR PUSTAKA}

Clara Novita A, Literasi Media baru dan penyebaran informasi HOAX, Yogyakarta, Universitas Gajah Mada, Tesis, 2015, tidak dipublikasikan

Herlina, D. (2011). Gerakan Literasi Media Indonesia. Yogyakarta: Rumah Sinema

Idi Subandi dan Bachruddin Ali Akhmad, Komunikasi dan komodifikasi(,Jakarta: Yayasan Pustakan Obor Indonesia,)2014

Muhamad Heychel, Mukjizat televise, dalam Yovantra Arief, Orde Media,2015, Yogyakarta, Insist press

Roy Thaniago, Orde Media : sebuah Pengantar dalam Yovantra Arief, Orde Media, Yogyakarta : Insistpress,2015

Suprati, E. (2011). Pelatihan Literasi Media dengan Metode Kreatif untuk Remaja.

Yogyakarta: Rumah Sinema,

Yosal Iriantara,2009, Literasi Media, Bandung: Simbiosa Rekatama Media

Zamroni, M., \& Sukiratnasari. (2011). KPID DIY Membumikan Literasi Media Bagi Masyarakat di Daerah Istimewa Yogyakarta. In D. Herlina, Gerakan Literasi Media Indonesia . Yogyakarta: Rumah Sinema,. 